University of Nebraska - Lincoln

DigitalCommons@University of Nebraska - Lincoln

1993

Exceptionally Well-Preserved Early Oligocene Diatoms from

Glacial Sediments of Prydz Bay, East Antarctica

John A. Barron

USGS

Albert D. Mahood

California Academy of Sciences, San Francisco, California

Follow this and additional works at: https://digitalcommons.unl.edu/usgsstaffpub

Part of the Earth Sciences Commons

Barron, John A. and Mahood, Albert D., "Exceptionally Well-Preserved Early Oligocene Diatoms from Glacial Sediments of Prydz Bay, East Antarctica" (1993). USGS Staff -- Published Research. 266.

https://digitalcommons.unl.edu/usgsstaffpub/266

This Article is brought to you for free and open access by the US Geological Survey at DigitalCommons@University of Nebraska - Lincoln. It has been accepted for inclusion in USGS Staff -- Published Research by an authorized administrator of DigitalCommons@University of Nebraska - Lincoln. 


\title{
Exceptionally well-preserved early Oligocene diatoms from glacial sediments of Prydz Bay, East Antarctica
}

\author{
John A. Barron ${ }^{1}$ and Albert D. Mahood ${ }^{2}$ \\ ${ }^{1}$ U.S. Geological Survey, Menlo Park, California 94025 \\ ${ }^{2}$ California Academy of Sciences, San Francisco, California 94118-9961
}

\begin{abstract}
An exceptionally well-preserved early Oligocene diatom assemblage is documented and illustrated from the internal sediment of a gastropod shell, which was collected from glacial sediments recovered at Ocean Drilling Program Site 739 on the continental shelf in Prydz Bay, Antarctica. The diatoms were deposited between 35.9 and $34.8 \mathrm{Ma}$ according to diatom and calcareous nannofossil stratigraphy, apparently soon after a period of major ice sheet advance across the Prydz Bay continental shelf. The diatom assemblage is neritic in character, but it can readily be correlated with open ocean assemblages from the Southern Ocean as well as with similar material recovered from the CIROS-1 drillhole in the Ross Sea.
\end{abstract}

\section{INTRODUCTION}

Early Oligocene diatoms were recovered from a $13 \mathrm{~m}$-thick sequence of glacial sediments in Cores 739C-25R through -39R of Ocean Drilling Program Leg 119, Hole 739C in Prydz Bay, Antarctica (Baldauf and Barron 1991; Barron et al. 1991a). Site 739 is located about $30 \mathrm{~km}$ landward from the shelf edge in Prydz Bay where seismic stratigraphy indicated there was a transition from generally flat-lying seismic reflectors that characterize the middle parts of the Prydz Bay continental shelf to prograding reflectors that are typical of the outer part of the shelf (text-fig. 1) (Cooper et al. 1991). Site 739 was chosen in hopes that this transition of seismic reflector character would represent a transition from nonglacial to glacial sediments (Barron et al. 1989). A 486.8m-thick section of glacial diamictite was cored at Site 739 without reaching preglacial sediments.

The lower Oligocene diatom assemblage recovered from Cores 739C-25R through $-39 \mathrm{R}$ closely resembles Assemblage Zone B of Harwood (1989) which was recovered from the CIROS-1 drill hole in the western McMurdo Sound area of west Antarctica (Baldauf and Barron 1991; D. M. Harwood, pers. comm., 1989). Harwood et al. (1989) assigned an age of 36.0-34.5 Ma to Assemblage Zone B within the Rhizosolenia oligocaenica Zone. Calcareous nannofossil stratigraphy from Site 739 suggest a similar age for the diatom assemblage, although calcareous nannofossils are very sporadic, show very low diversity and may be reworked (Wei and Thierstein 1991). The presence of the calcareous nannofossil Isthmolithus recurvus in Samples 119- 739C-28R-1, 30-32cm and 119-739C-30R-1, 108-110cm suggests a late Eocene to early Oligocene age (38.8-34.8 Ma) within the Isthmolithus recurvus Zone to Blackities spinosus Zone (Wei and Thierstein 1991). Dinoflagellate assemblages recovered from Cores 119-739C-41R, 119-739C-47R, and 119739C-51R (331, 386 and 426 meters below seafloor [mbsf], respectively) belong to a provincial Antarctic flora of Eocene to early Oligocene age according to Truswell (1991) and also support the diatom and calcareous nannofossil stratigraphies.

Because the early Oligocene age suggested by these microfossils was in conflict with a late Oligocene to early Miocene age obtained from strontium isotope studies on molluscan shells
(Thierstein et al. 1991), one of the gastropod (Amauropsis sp.) shells from Sample 119-739C-30R-1, 108cm was broken open and its sediment contents were examined for diatoms (Barron et al. 1991a). Exceptionally well-preserved early Oligocene diatoms including a $400 \mu \mathrm{m}$-long delicate frustule of Sceptroneis lingulatus and frustules of Pyxilla joined by their apical spines were obtained from the internal sediment of the gastropod shell. Barron et al. (1991a) argued that these diatoms were probably not reworked into younger sediments. Furthermore, the absence of such distinctive diatoms as Cymatosira biharensis, Azpeitia oligocenica, Asteromphalus symmetricus, Stephanopyxis spino-

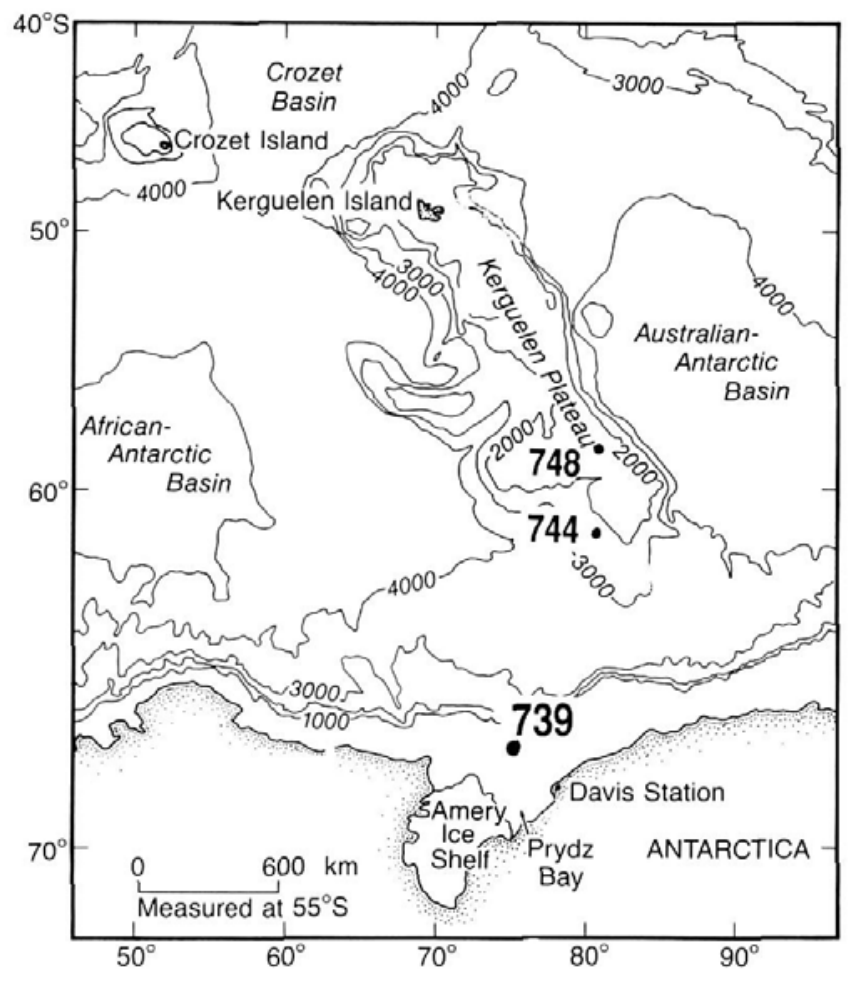

TEXT-FIGURE 1

Location map of ODP Site 739 in Prydz Bay, Antarctica and Sites 744 and 748 on the Kerguelen Plateau. Contours in meters. 
TABLE 1

Diatom taxon frequency in Sample 119-739C-30R-1, $108 \mathrm{~cm} . *$ not observed in the frequency count but observed in the sample; $+=$ represents less than $1 \%$ of the diatom assemblage.

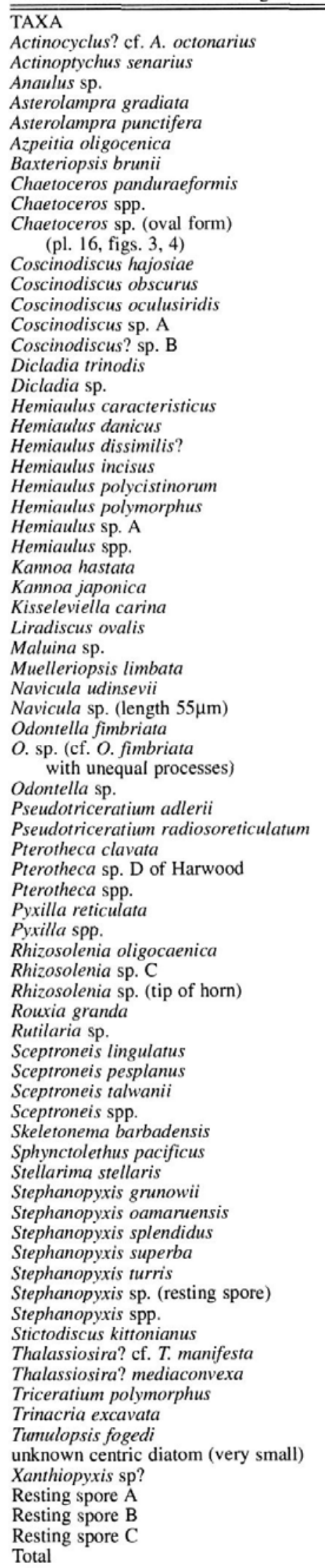

sissima, S. vasta, Synedra jouseana, Rocella vigilans and Lisitzinia ornata, which have been documented in late Oligocene assemblages from throughout the Southern Ocean (Gombos and Ciesielski 1983; Baldauf and Barron 1991) and on the Antarctic continental shelf (Harwood 1986, 1989), argues against a late Oligocene age.

The strontium isotope ages were concluded to be in error, possibly due to abnormally high concentrations of strontium measured in pore waters of the sediments and which were associated with large quantities of fresh igneous and metamorphic debris found in the glacial sediments (Barron et al. 1991a).

Further study of the diatoms from the gastropod mold was warranted by their excellent state of preservation and their importance in dating glacial sediments which imply an extensive early Oligocene ice sheet in Prydz Bay, Antarctica, (Barron et al. 1991b). Diatoms in this important assemblage are documented, illustrated and tabulated in the present paper. Some new and taxonomically interesting taxa are treated in detail in a companion paper by Mahood et al. (in press).

\section{METHODS AND MATERIALS}

The sediment from ODP Leg 119 Hole 739C-30R-1, 108cm, was processed for light (LM) and scanning electron (SEM) microscopy by the Van der Werff (1955) hydrogen peroxide method. Strewn slides were prepared for light microscopy using the mounting medium Hyrax. Forty strewn slides (some with $15 \mathrm{~mm}$-diameter circular cover slides and others with rectangular cover slides $22 \times 30 \mathrm{~mm}$ ) were examined in entirety using either a Leitz Ortholux II or an Olympus IMT at $\times 500$ and $\times 1250$. Light microscope photography was also completed using these microscopes. Four hundred fifty diatom valves were arranged on four SEM stubs for examination and photography using a Cambridge 250 Mark II SEM at the U.S. Geological Survey in Menlo Park and a Hitachi S520 at the California Academy of Sciences.

\section{RESULTS}

Forty strewn slides and four picked and mounted SEM stubs were examined. The diatom taxa encountered during examination are listed and discussed in Appendix 1. The frequency of their occurrence in a smear slide count of 379 individuals is presented in table 1. Many of these taxa are illustrated in plates 1-7 as well as in Mahood et al. (in press).

Sixty-four diatom taxa including resting spore forms have been recorded from the gastropod mold sample, but at least 10 other taxa are present. The relatively high numbers of Hemiaulus, Sceptroneis and Stephanopyxis forms are typical for an outer shelf to upper slope assemblage, and resting spores are also fairly common (table 1). Truly benthic taxa (Navicula spp., Rutilaria spp.) are relatively rare. Planktonic diatom taxa such as Asterolampra, Azpeitia, Coscinodiscus, Pyxilla, Rhizosolenia and Triceratium are relatively numerous, so that comparison with other early Oligocene diatom assemblages from the Southern Ocean is possible.

\section{DIATOM BIOSTRATIGRAPHY}

The diatom assemblage of Sample 739C-30R-1, 108cm correlates best with the upper part of Harwood's (1989) Assemblage Zone B from the Ross Sea based on the presence of Triceratium polymorphus (=T. hebetatum of Harwood 1989), Asterolampra punctifera, Cotyledon fogedi (= Tumulopsis fogedi of this 


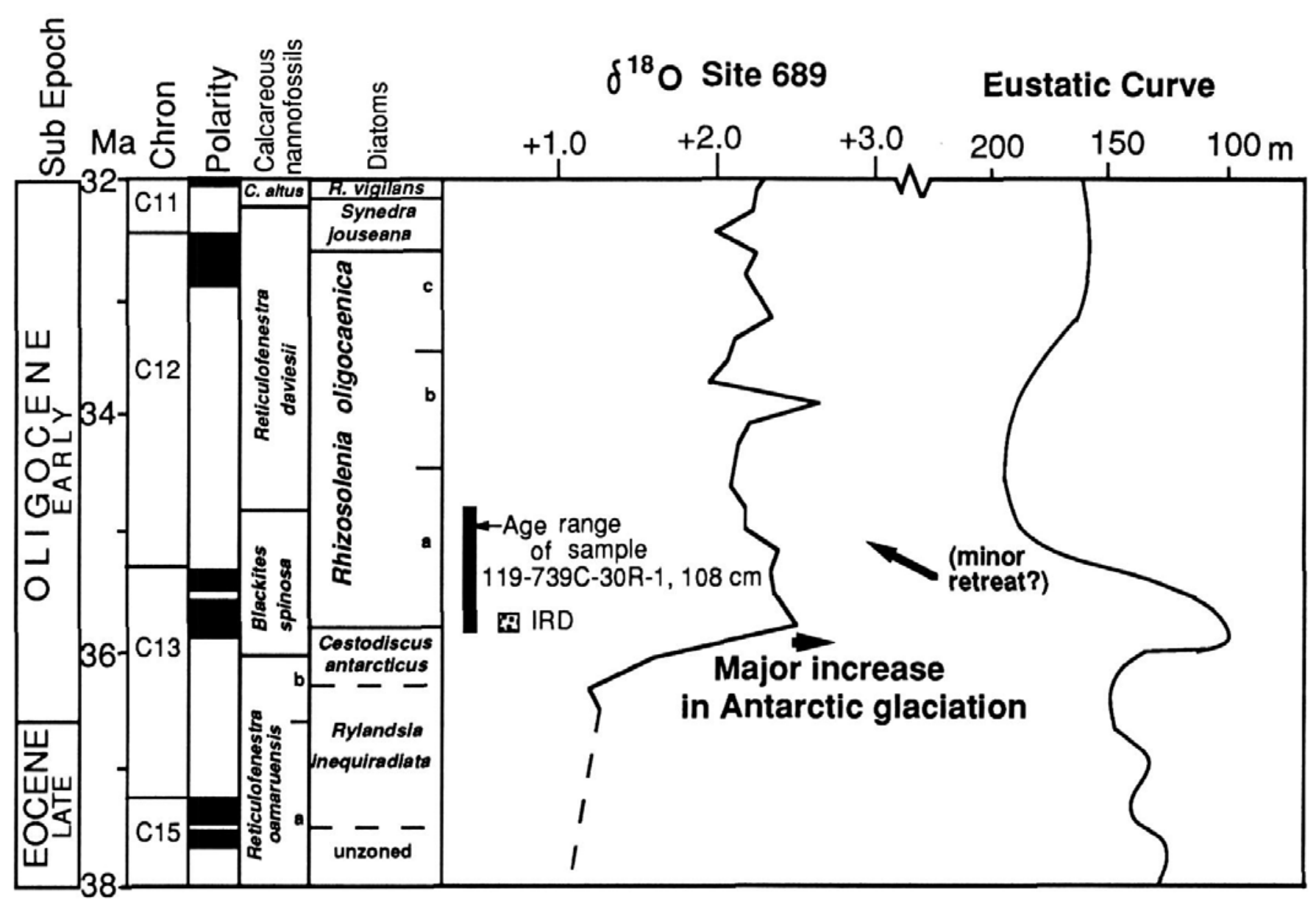

TEXT-FIGURE 2

Correlation of the diatom assemblage of Sample 119-739C-30R-1, 108cm to geologic time, the oxygen isotope curve for ODP Site 689 of Kennett and Stott (1990), and the eustatic curve of Haq et al. (1987). Calcareous nannofossil zones after Wei and Thierstein (1991); diatom zones after Harwood and Maruyama (in press) for the Oliogcene and after Fenner (1985) for the late Eocene; geologic time scale and magnetic polarity scale after Berggren et al. (1985); IRD = interval of ice-rafted detritus at Sites 744 and 748.

report), Rhizosolenia oligocaenica, Sceptroneis lingulatus, Stephanopyxis splendidus and Pyxilla reticulata. Harwood et al. (1989) correlate this interval with the Rhizosolenia oligocaenica Zone and assign an age of 36.0-34.5 Ma to this interval, which is truncated by an overlying unconformity in the CIROS-1 drillhole. As mentioned earlier, the presence of the calcareous nannofossil Isthmolithus recurvus in Sample 119-739C-30R-1, $108-110 \mathrm{~cm}$ would seem to further constrain the age of this interval to no younger than $34.8 \mathrm{Ma}$ (Wei and Thierstein 1991).

Early Oligocene provincialism (Fenner 1985; Harwood 1989, 1991; Baldauf 1992) makes it difficult to correlate the Prydz Bay diatom assemblage with more oceanic diatom assemblages recorded from the lower Oligocene of the Southern Ocean (Baldauf and Barron 1991). In referring to Gombos and Ciesielski's (1983) South Atlantic DSDP Site 511, the diatom assemblage of Sample 119-739C-30R-1, 108cm correlates best with the lower Oligocene interval of Samples 71-511-12-1, $11-13 \mathrm{~cm}$ through $-13-1,6-8 \mathrm{~cm}$ based on the restricted occurrences of $T$. polymorphus (recorded as $T$. macroporum [concave form]), $R$. oligocaenica (recorded as $R$. gravida), Asterolampra gradiata, Baxteriopsis brunii (recorded as Baxteria brunii) and S. splendidus (recorded as Thalassiosira hydra) (Gombos and Ciesielski 1983). This interval is assigned to the Melosira architecturalis Zone through lower Brightwellia spiralis Zone by Gombos and Ciesielski (1983) at DSDP Site 511 but is equivalent to the lower portion of the Rhizosolenia oligocaenica Zone.

The assemblage correlates with Samples 748B-13H-6, 116$118 \mathrm{~cm} ;-13 \mathrm{H}, \mathrm{CC}$ and $-14 \mathrm{H}-1,52-54 \mathrm{~cm}$ of Harwood and Maruyama (1992). Of these three, correlation is best with Sample $-13 \mathrm{H}-6$ based on the presence of Rouxia granda, Sceptroneis grunowii, S. pesplanus and the isolated occurrence of $S$. lingulatus in that sample. It is thus correlative to Subzone a of the Rhizosolenia oligocaenica Zone of Harwood and Maruyama (1992) to which they assign an age of 35.5-34.5 Ma. Barron et al. (1991a), however, place the base of this subzone at $35.9 \mathrm{Ma}$ based on correlation with magnetostratigraphy at nearby Site 744. Other taxa supportive of this correlation are Triceratium polymorphus and Asterolampra gradiata. Such a correlation suggests that the Prydz Bay assemblage of Sample 119-739C30R-1, 108cm was deposited immediately following the deposition of a pulse of ice-rafted detritus (IRD), which was documented by Shipboard Scientific Party (1989a) between Samples 120-748B-14H-1, 137-150cm and $-14 \mathrm{H}-2,0-24 \mathrm{~cm}$. Because a 1.5 per mil increase in the $\delta^{18} \mathrm{O}$ of benthic foraminifers was measured by Zachos et al. (1992) within the same IRD 
horizon, the Prydz Bay sample seemingly was deposited just after the oxygen isotope event.

Subsequent study by the senior author of Baldauf and Barron's (1991) samples from ODP Site 744 on the southern Kerguelen Plateau reveals that Sample 119-739C-30R-1, 108cm is most similar to Sample 119-744A-16-6, 60-62 cm based on the co-occurrence of Asterolampra gradiata, A. punctifera, $R$. oligocaenica and $T$. polymorphus. As at Site 748, IRD was found immediately below in Section 744A-16H-7 (Shipboard Scientific Party 1989b). At Site 744 a similar major $\delta^{18} \mathrm{O}$ increase of 1.15 per mil was recorded by Barrera and Huber (1991) in benthic foraminifers between Samples 119-744A$18 \mathrm{H}-2,95 \mathrm{~cm}$ and $-16-6,95 \mathrm{~cm}(150.07-145.67 \mathrm{mbsf})$, which is just below the diatom assemblage that correlates best with that of the gastropod mold. This earliest Oligocene isotopic event, recorded at Sites 748 and 744 , is recognized globally (Kennett and Stott 1990) and presumably signals a major growth of an ice sheet in East Antarctica (Barron et al. 1991b). The calcareous nannofossil I. recurvus suggests a minimum age of $34.8 \mathrm{Ma}$ (Blackities spinosus Zone), whereas the diatom Rhizosolenia oligocaenica argues for a maximum age of $35.9 \mathrm{Ma}(R$. oligocaenica Zone, Subzone a). Thus, Sample 119-739C-30R-1, $108 \mathrm{~cm}$ appears to have been deposited soon after this period of major ice sheet growth in the earliest Oligocene (ca. 35.9 to 34.8 $\mathrm{Ma})$, perhaps during a period of minor retreat or stability in the ice sheet (Barron et al. 1991b; Hambrey et al. 1991) (text-fig. 2).

\section{ENVIRONMENT OF DEPOSITION}

The gastropod shell of Sample 119-739C-30R-1, 108cm was taken from a weakly to well stratified diamictite, which is interpreted by Hambrey et al. (1991) to represent proximal glaciomarine sediment subject to periodic strong current reworking. Based on seismic stratigraphy, the unit containing the early Oligocene diatoms consists of sediments deposited on the upper paleo-continental slope between the continental shelf break and a level 200m down-slope (Cooper et al. 1991). With the grounding point of the ice shelf at the shelf break, this implies a free seawater connection beneath the floating ice shelf to the points of deposition. The presence of well-preserved benthic taxa such as Navicula would seem to imply that at least parts of the shelf were free from ice cover during parts of the year. Thus, deposition on the upper slope seaward of an ice sheet is envisioned. Presumably, the sediment entered the shell shortly after the death of the gastropod, and the shell provided some protection from bioturbational and other mechanical reworking of the sediment which would normally cause abrasion, fragmentation and dissolution of the diatom frustules.

\section{SUMMARY COMMENTS}

An exceptionally well-preserved diatom assemblage containing over 65 different taxa is documented and illustrated from glacial sediments recovered from ODP Site 739 on the outer continental shelf in Prydz Bay, Antarctica. The neritic assemblage correlates with Harwood's (1989) Assemblage Zone B from the CIROS-1 drillhole in the Ross Sea and with Harwood and Maruyama's (1992) Subzone a of the Rhizosolenia oligocaenica Zone and is earliest Oligocene in age, approximately 35.9-34.8 $\mathrm{Ma}$. It is suggested that the assemblage was deposited soon after a major expansion of the ice sheet in East Antarctica, possibly during a minor phase of retreat of that ice sheet. The excellent preservational state of the diatom assemblage is probably due to the protection from mechanical and bioturbational abrasion and subsequent dissolution which was provided by a gastropod shell.

\section{ACKNOWLEDGMENTS}

The gastropod mold sample was collected by Birger Larsen of the Geological Survey of Denmark and was provided by the Ocean Drilling Program. Robert Oscarson of the U.S. Geological Survey and Lisa Borock of the California Academy of Sciences assisted in the SEM photography. Patricia Sims of the British Museum of Natural History and Pat Kociolek of the California Academy of Sciences are thanked for their helpful comments. The manuscript benefited from the reviews of David Harwood of the University of Nebraska-Lincoln and Jack Baldauf of the Ocean Drilling Program and Texas A\&M University.

\section{REFERENCES}

AKIBA, F., 1986. Middle Miocene to Quaternary diatom biostratigraphy in the Nankai Trough and Japan Trench, and modified lower Miocene through Quaternary diatom zones for middle-to-high latitudes of the North Pacific. In: Kagami, H., Karig, D. E., Coulbourn, W. T. et al., Initial Reports of the Deep Sea Drilling Project, Volume 87: 393-481. Washington, D.C.: U.S. Government Printing Office.

BALDAUF, J. G., 1992. Middle Eocene through early Miocene diatom evolution. In: Berggren, W. A., and Prothero, D., Eocene-Oligocene Climatic and Biotic Evolution. Princeton: Princeton University Press, pp. 310-326.

BALDAUF, J. G. and BARRON, J. A., 1987. Oligocene marine diatoms recovered in dredge samples from the Navarin Basin province, Bering Sea. U.S. Geological Survey Bulletin 1765, 17 pp., 14 pls.

1991. Diatom biostratigraphy: Kerguelen Plateau and Prydz Bay regions of the Southern Ocean. In: Barron, J. A., Larsen, B. et al., Proceedings of the Ocean Drilling Program, Science Results, Volume 119B:547-598. College Station, TX: Ocean Drilling Program.

BARRERA, E. and HUBER, B. T., 1991. Paleocene and early Neogene oceanography of the southern Indian Ocean: Leg 119 foraminifera stable
1a,b Coscinodiscus oculusiridis Ehrenberg. 1a, diameter $274 \mu \mathrm{m} ; 1 \mathrm{~b}$, center.
2 Coscinodiscus sp. A. compare with Aulacodiscus (radius $63 \mu \mathrm{m})$.

PLATE 1

$\begin{aligned} 3 & \text { Coscinodiscus hajosiae Fenner (diameter } 82 \mu \mathrm{m} \text { ). } \\ 4,5 & \begin{array}{l}\text { Stellarima stellaris (Roper) Hasle and Sims. } 4 \text {, diameter } \\ 45 \mu \mathrm{m} ; 5 \text {, diameter } 27 \mu \mathrm{m} .\end{array} \\ 6 & \text { Azpeitia oligocenica (Jousé) Sims (diameter } 45 \mu \mathrm{m} \text { ). }\end{aligned}$



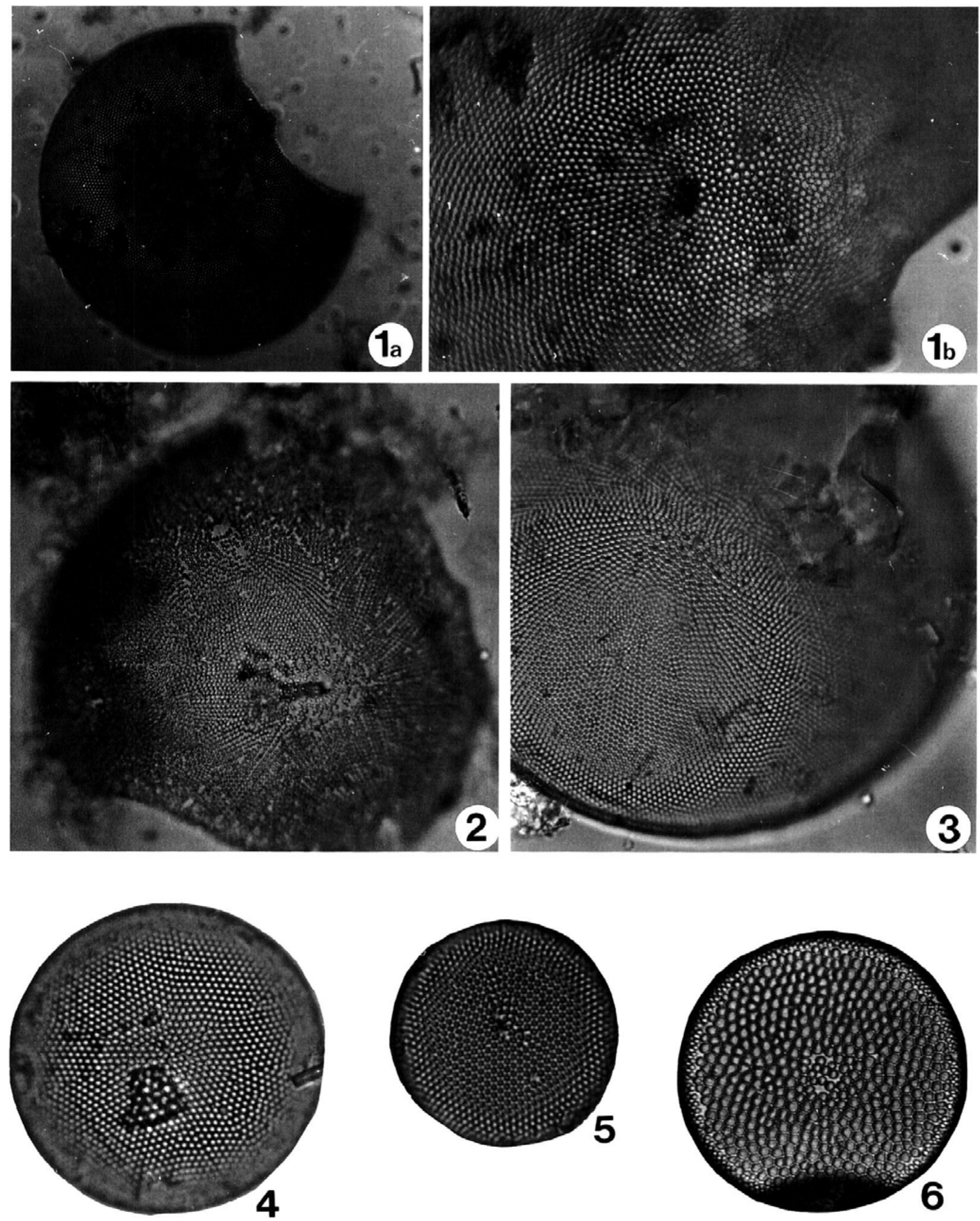
isotope results. In: Barron, J. A., Larsen, B. et al., Proceedings of the Ocean Drilling Program, Science Results, Volume 119B:693-717. College Station, TX: Ocean Drilling Program.

BARRON, J. A., BALDAUF, J. G., BARRERA, E., CAULET, J.-P., HUBER, B. T., KEATING, B. H., LAZURUS, D., SAKAI, H., THIERSTEIN, H. R. and WEI, W., 1991a. Biochronologic and magnetochronologic synthesis of ODP Leg 119 sediments from the Kerguelen Plateau and Prydz Bay, Antarctica. In: Barron, J. A., Larsen, B. et al., Proceedings of the Ocean Drilling Program, Science Results, Volume 119B:813-847. College Station, TX: Ocean Drilling Program.

BARRON, J. A., LARSEN, B. et al., 1989. Proceedings Ocean Drilling Program, Initial Reports, Volume 119A. College Station, TX: Ocean Drilling Program, 942 pp.

BARRON, J. A., LARSEN, B. and BALDAUF, J. G., 1991b. Evidence for late Eocene-early Oligocene Antarctic glaciation and observations on late Neogene glacial history of Antarctica: Results from ODP Leg 119. In: Barron, J. A., Larsen, B. et al., Proceedings of the Ocean Drilling Program, Science Results, Volume 119B:869-891. College Station, TX: Ocean Drilling Program.

BERGGREN, W. A., KENT, D. V., FLYNN, J. J. and VAN COUVERING, J. A., 1985. Cenozoic geochronology. Geological Society of America Bulletin, 96:1407-1418.

BRUN, J., 1891. Diatomees espèces nouvelles marines, fossiles ou pèlagiques. Memoires de la Société de Physique d'Histoire Naturelle de Genève, $31(1): 1-47$.

COOPER, A. K., STAGG, H. and GEIST, E., 1991. Seismic stratigraphy and structure of Prydz Bay, Antarctica: Implications from ODP Leg 119 drilling. In: Barron, J. A., Larsen, B. et al., Proceedings of the Ocean Drilling Program, Science Results, Volume 119B:5-25. College Station, TX: Ocean Drilling Program.

DE TONI, J. B., 1894. Sylloge algarum omnium hucusque cognitarum, Volume II, Sectio III, Cryptoraphideae. Patavii: Typis Seminarii, p. 818-1556.

FENNER, J., 1978. Cenozoic diatom biostratigraphy of the equatorial and southern Atlantic Ocean. In: Perch-Nielsen, K., Supko, P. R. et al., Initial Reports of the Deep Sea Drilling Project, Supplement Volume 39:491623. Washington, D.C.: U.S. Government Printing Office.

1984. Eocene-Oligocene planktic diatom stratigraphy in the low latitudes and high southern latitudes. Micropaleontology, 30:319-342.

, 1985. Late Cretaceous to Oligocene planktic diatoms. In: Bolli, H.M, Saunders, J. B. and Perch-Nielsen, K., Eds., Plankton stratigraphy, Cambridge, UK: Cambridge University Press, pp. 713-762.

GOMBOS, A. M, JR., 1976. Paleocene and Neogene diatoms from the Falkland Plateau and Malvinas outer basin, Leg 36, Deep Sea Drilling
Project. In: Barker, P. F., Dalziel, I. W. D. et al., Initial Reports of the Deep Sea Drilling Project, Volume 36:575-687. Washington, D.C.: U.S. Government Printing Office.

GOMBOS, A. M., JR. and CIESIELSKI, P. F., 1983. Late Eocene to early Miocene diatoms from the southwest Atlantic. In: Ludwig, W. J., Krasheninikov, V. A. et al., Initial Reports of the Deep Sea Drilling Project, Volume 71:583-634. Washington, D.C.: U.S. Government Printing Office.

HAJOS, M., 1976. IV. Upper Eocene and lower Oligocene Diatomaceae, Archaeomonadaceae and Silicoflagellatae in southwestern Pacific sediments, DSDP Leg 29. In: Hollister, C. D., Craddock, C. et al., Initial Reports of the Deep Sea Drilling Project, Volume 35:817-883. Washington, D.C.: U.S. Government Printing Office.

HAMBREY, M. J., EHRMANN, W. U. and LARSEN, B., 1991. Cenozoic glacial record of the Prydz Bay continental shelf, East Antarctica. In: Barron, J. A., Larsen, B. et al., Proceedings of the Ocean Drilling Program, Science Results, Volume 119B:77-132. College Station, TX: Ocean Drilling Program.

HARWOOD, D. M., 1986. Diatoms. In: Barrett, P. J., Ed., Antarctic Cenozoic history from the MSST-1 drillhole, McMurdo Sound. Department of Scientific and Industrial Research Bulletin, 237:69-109. Wellington, New Zealand: D.S.I.R. Publishing.

1989. Siliceous microfossil biostratigraphy. In: Barrett, P. J., Ed., Antarctic Cenozoic history from the CIROS-1 drillhole, McMurdo Sound. Department of Scientific and Industrial Research Bulletin, 245:67-97. Wellington, New Zealand: D.S.I.R. Publishing.

1991. Cenozoic diatom biogeography in the southern high latitudes: Inferred biogeographic barriers and progressive endemism. In: Thompson, M. R. A., Crane, A. and Thompson, J., Eds., Geological Evolution of Antarctica. Cambridge: Cambridge University Press, pp. 667-673.

HARWOOD, D. M., BARRETT, P. J., EDWARDS, A. R., RIECK, H. J. and WEBB, P.-N., 1989. Biostratigraphy and chronology. In: Barrett, P. J., Ed., Antarctic Cenozoic history from the CIROS-1 drillhole, McMurdo Sound. Department of Scientific and Industrial Research Bulletin, 245:231-239. Wellington, New Zealand: D.S.I.R. Publishing.

HARWOOD, D. M. and MARUYAMA, T., 1992. Middle Eocene to Pleistocene diatom biostratigraphy of Southern Ocean sediments from the Kerguelen Plateau, ODP Leg 120. In: Schlich, R., Wise, S. W., Jr., Palmer, A. et al., Proceedings of the Ocean Drilling Program, Science Results, Volume 120B:683-733. College Station, TX: Ocean Drilling Program.

HAQ, B. U., HARDENBOL, J. and VAIL, P. R., 1987. Chronology of fluctuating sea level since the Triassic. Science, 235:1156-1167.

\section{PLATE 2}

1, 2 Stephanopyxis grunowii Grove and Sturt in Schmidt. 1a, b, c, low to high focus, diameter $67 \mu \mathrm{m} ; 2$, diameter $37.6 \mu \mathrm{m}$.

3, 4 Stephanopyxis superba (Greville) Grunow. 3, diameter $27 \mu \mathrm{m} ; 4$, diameter $23 \mu \mathrm{m}$.

5 Stephanopyxis oamaruensis Hajós (diameter $69.5 \mu \mathrm{m}$ ).
6 Actinoptychus senarius (Ehrenberg) Ehrenberg (diameter $45 \mu \mathrm{m})$.

7,9, Tumulopsis fogedi Hendey. 7, 10, ornamented valves,

10 diameters $31.2 \mu \mathrm{m}$ and $31.2 \mu \mathrm{m}$; 9 , plain valve, diameter $55.3 \mu \mathrm{m}$.

8 Stictodiscus kittonianus Greville (diameter $42 \mu \mathrm{m}$ ). 


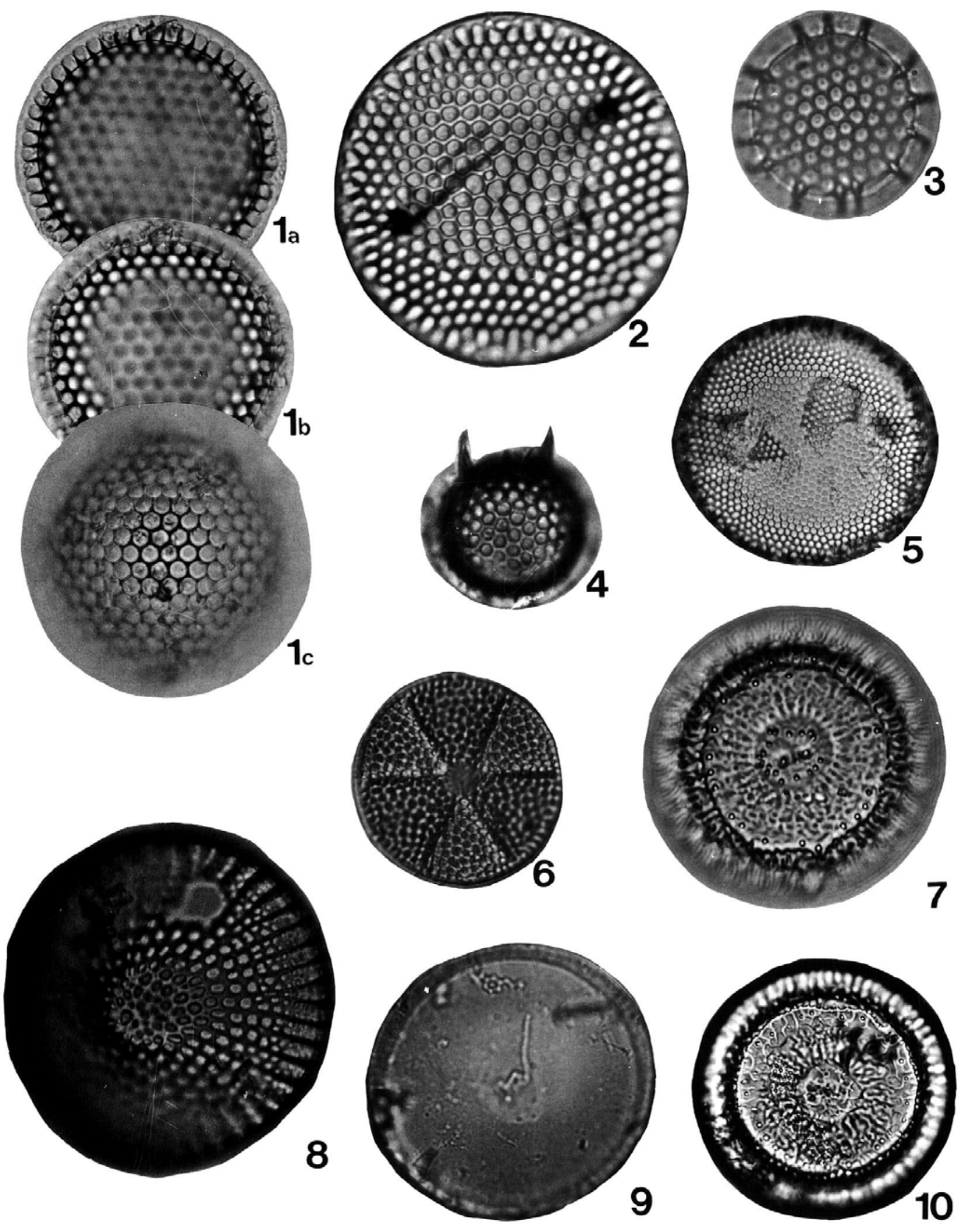


HENDEY, N. I., 1982. Tumulopsis fogedi, gen. et spec. nov. An unusual diatom from a South Atlantic Eocene core. Beihefte zur Nova Hedwigia, $73: 275-280$.

HUSTEDT, F. , 1930. Die Kieselalgen, Deutschlands, Östereichs und der Schweiz. In: Rabenhorst, L., Ed., Kryptogamen-Flora von Deutschland, Östereichs und der Schweiz, Band VII, 1 Teil, 920 pp. Reprint 1977, Koenigstein, Germany: Otto Koeltz Science Publishers.

KENNETT, J. P. and STOTT, L. D., 1990. Proteus and proto-oceanus: ancestral Paleocene oceans as revealed from Antarctic stable isotopic results: ODP Leg 113. In: Barker, P. F., Kennett, J. P. et al., Proceedings of the Ocean Drilling Program, Volume 113B:865-880. College Station, TX: Ocean Drilling Program.

KOMURA, S., 1980. A new genus of cuneate diatom from the Miocene Masuporo Formation of the Tenpoku district, Japan. Professor Saburo Kanno Memorial Volume. Tsukuba, Japan: Tsukuba Univ. Press, pp. 373-378.

MAHOOD, A. D., BARRON, J. A. and SIMS, P. A., in press. A study of some unusual, well preserved Oligocene diatoms from Antarctica. Beihefte zur Nova Hedwigia (Ross Commemorative Volume).

ROSS, R. and SIMS, P. A., 1987. Further genera of the Biddulphiaceae (diatoms) with interlocking linking spines. Bull. British Museum (Natural History), 16(4):269-311.

SCHMIDT, A. et al. 1874-1959. Atlas der Diatomaceen-Kunde, Tafeln 1-480. Leipzig, Germany: O. R. Reisland.

SCHRADER, H.-J., 1976. Cenozoic planktonic diatom biostratigraphy of the southern Pacific Ocean. In: Hollister, C. D., Craddock, C. et al., Initial Reports of the Deep Sea Drilling Project, Volume 35:605-671. Washington, D.C.: U.S. Government Printing Office.

SCHRADER, H.-J. and FENNER, J., 1976. Norwegian Sea Cenozoic diatom biostratigraphy and taxonomy. Part 1. Norwegian Sea Cenozoic diatom biostratigraphy. In: Talwani, M., Udintsev, G. et al., Initial Reports of the Deep Sea Drilling Project, Volume 38:921-1098. Washington, D.C.: U.S. Government Printing Office.

SHIPBOARD SCIENTIFIC PARTY, 1989a. Site 748. In: Schlich, R., Wise, S. W., Jr., Palmer, A. et al., Proceedings of the Ocean Drilling Program, Initial Reports, Volume 120A:157-235. College Station, TX: Ocean Drilling Program.

1989b. Site 744. In: Barron, J. A., Larsen, B. et al., Proceedings of the Ocean Drilling Program, Initial Reports, Volume 119A:477-504. College Station, TX: Ocean Drilling Program.
SIMS, P. A., 1986. Sphynctolethus Hanna, Ailuretta gen. nov., and evolutionary trends within the Hemiauloideae. Diatom Research, 1(2):241-269.

SIMS, P. A., FRYXELL, G. A. and BALDAUF, J. G., 1989. Critical examination of the diatom genus Azpeitia: Species useful as stratigraphic markers for the Oligocene and Miocene Epochs. Micropaleontology, 35(4):293-307.

STRELNIKOVA, N. I. and NIKOLAEV, V. A., 1989. New data on the morphology and systematic position of the genus Pyxilla (Bacillariophyta). Botanical Journal, 74(2):247-248. [In Russian]

THIERSTEIN, H. R., MACDOUDALL, D. D., MARTIN, E. E., LARSEN, B., BARRON, J. A. and BALDAUF, J. G., 1991. Age determinations of Paleocene diamictites from Prydz Bay (ODP Site 739), Antarctica, using $\mathrm{Sr}$ isotopes of mollusks and biostratigraphy of microfossils (diatoms and coccoliths). In: Barron, J. A., Larsen, B. et al., Proceedings of the Ocean Drilling Program, Science Results, Volume 119B:739-745. College Station, TX: Ocean Drilling Program.

TRUSWELL, E. M., 1991. Palynology of sediments from Leg 119 drill sites in Prydz Bay, East Antarctica. In: Barron, J. A., Larsen, B. et al., Proceedings of the Ocean Drilling Program, Science Results, Volume 119B:941-945. College Station, TX: Ocean Drilling Program.

VAN DER WERFF, A., 1955. A method of concentrating and cleaning diatoms and other organisms. International Association of Theoretical and Applied Limnology Proceedings, 12:276-277.

VAN HEURCK, H., 1896. A Treatise on the Diatomaceae. Translated by W. E. Baxter. London: William Wesley \& Son, pp. 1-558.

WEI, W. and THIERSTEIN, H. R., 1991. Upper Cretaceous and Cenozoic calcareous nannofossils of the Kerguelen Plateau (southern Indian Ocean) and Prydz Bay (East Antarctica). In: Barron, J. A., Larsen, B. et al., Proceedings of the Ocean Drilling Program, Science Results, Volume 119B:467-493. College Station, TX: Ocean Drilling Program.

ZACHOS, J. C., BERGGREN, W. A., AUBRY, M.-P. and MACKENSEN, A., 1992. Eocene-Oligocene climatic and abyssal circulation history of the southern Indian Ocean. In: Schlich, R., Wise, S. W., Jr., Palmer, A. et al., Proceedings of the Ocean Drilling Program, Science Results, Volume 120B:839-854. College Station, TX: Ocean Drilling Program.

Manuscript received November 4, 1991

Manuscript accepted April 27, 1992

\section{PLATE 3}

1, 2a,b Pseudotriceratium adlerii Mahood. 1, base $110 \mu \mathrm{m} ; 2$, low and high focus, base $95 \mu \mathrm{m}$.

3 Trinacria excavata Heiberg (base $75 \mu \mathrm{m}$ ).

4 a,b Pseudotriceratium sp. (low and high focus, base $41 \mu \mathrm{m}$ ).

$5 \quad$ Pseudotriceratium radiosoreticulatum Grunow in Van Heurck (base $38 \mu \mathrm{m}$ ).
6,9 Triceratium polymorphus Harwood and Maruyama, in press. 6 , base $40 \mu \mathrm{m} ; 9$, base $56 \mu \mathrm{m}$.

7 Hemiaulus sp. A (width $24 \mu \mathrm{m}$ ).

8 Dicladia $\mathrm{sp}$. (width $21 \mu \mathrm{m}$ )

10 Dicladia trinodis Hanna (width $55 \mu \mathrm{m}$ ) 


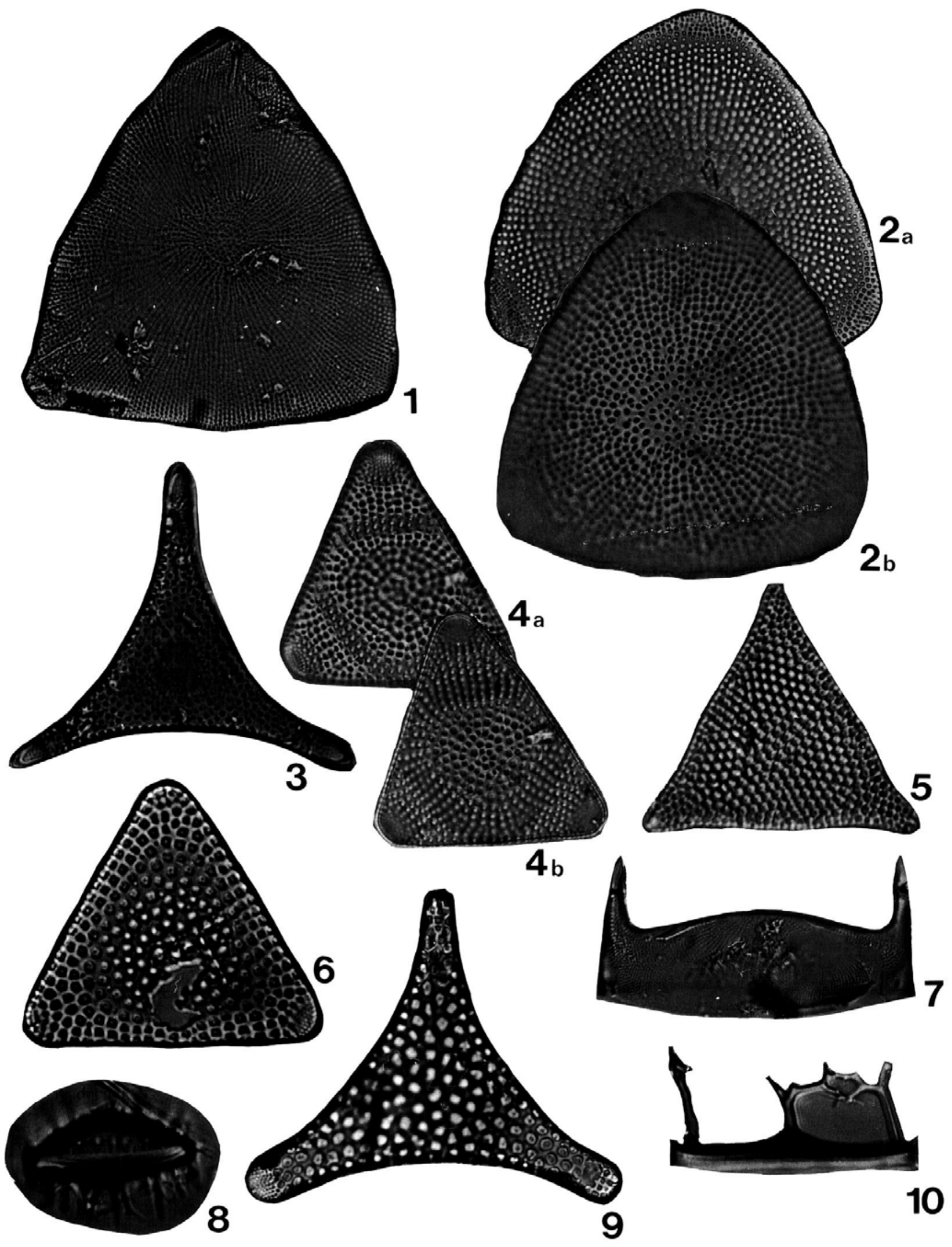


APPENDIX 1

List and remarks on diatom taxa

Actinocyclus? cf. A. octonarius Ehrenberg sensu Hajós 1976, p. 827 , pl. 9 , fig. 4 .

Actinoptychus senarius (Ehrenberg) Ehrenberg

Plate 2, figure 6

Remarks: Both typical forms and forms with quadrate-shaped valves were observed.

\section{Anaulus sp.}

Plate 4, figure 7

Remarks: Compare with figure 534 (Anaulus mediterraneus Grunow) in Hustedt 1930, v. 1, p. 893.

Asterolampra gradiata Gombos in Gombos and Ciesielski 1983, p. 606, pl. 1, figs. 4-6.

Plate 4, figure 10

Asterolampra punctifera (Grove) Hanna; Gombos and Ciesielski 1983, p. 600, pl. 2, figs. 4-8, pl. 5, figs. 8-10; Harwood 1989, p. 77, pl. 5, figs. 1,2 .

Plate 4 , figure 13

Azpeitia oligocenica (Jousé) Sims in Sims et al. 1989, p. 302, pl. 2, figs. 1-3, pl. 3, figs. 8, 9. As Coscinodiscus oligocenicus Jousé in Fenner 1978, p. 515, pl. 4, figs. 5-10.

Plate 1 , figure 6

Baxteriopsis brunii (van Heurck) Karsten; Fenner 1985, p. 726, figs. 10.7, 10.8. As Baxteria brunii van Heurck sensu Gombos and Ciesielski 1983, p. 600, pl. 21, figs. 5-7.

Plate 7, figure 8

Chaetoceros panduraeformis (Pantocsek) Gombos in Fenner 1978, p. 513 , pl. 36 , figs. $7,8,12$. As Xanthiopyxis panduraeformis Pantocsek, Schrader and Fenner 1976, p. 1003, pl. 45, fig. 7; Chaetoceros sp. A sensu Gombos 1976, p. 592, pl. 24, figs. 1-6.

Plate 5, figure 14; plate 6 , figures 6,7
Chaetoceros sp. (oval form)

Plate 6, figures 3,5

Coscinodiscus hajosiae Fenner 1984, p. 331, pl. 2, fig. 1; Fenner 1985, p. 728, fig. 7.25. As C. spiralis Hajós 1976, pl. 7, figs. 1-3. Plate 1, figure 3

Coscinodiscus obscurus A. Schmidt; Schrader and Fenner 1976, p. 976, pl. 33, fig. 1 .

Coscinodiscus oculusiridis Ehrenberg; Harwood 1989, p. 78, pl. 1, fig. 1.

Plate 1, figures $1 \mathrm{a}, \mathrm{b}$

\section{Coscinodiscus sp.? B}

Remarks: Figured as Thalassiosira bukryi (?) Barron by Harwood and Maruyama, 1992, pl. 2, figs. 13-14 (possibly not 15, $16)$.

Dicladia trinodis Hanna; Harwood 1989, pl. 4, fig. 22.

Plate 3, figure 10

\section{Dicladia sp.}

Plate 3, figure 8

Remarks: Compare specimen illustrated in Schrader and Fenner 1976, pl. 45, fig. 16.

\section{Fenestrella sp.}

Plate 1, figure 2

Remarks: Refer to Sims (1990); only one specimen observed.

Hemiaulus caracteristicus Hajós 1976, p. 828-829, pl. 15, fig. 10; Gombos and Ciesielski 1983, p. 602, pl. 20, figs. 1-5.

Plate 4 , figure 4

Remarks: The delicate mantle of this taxon is described in Mahood et al. (in press) for the first time.

\section{PLATE 4}

1 Odontella sp. cf. O. fimbriata (Greville) Schrader in Schrader and Fenner (form with unequal horns, width $41 \mu \mathrm{m})$.

2, 3 Rouxia granda Schrader in Schrader and Fenner. 2, length $37 \mu \mathrm{m} ; 3$, length $27 \mu \mathrm{m}$.

4 Hemiaulus caracteristicus Hajós (width $55 \mu \mathrm{m}$ ).

5 Odontella sp. (width between spines $80 \mu \mathrm{m}$ ).

6a, b Odontella fimbriata (Greville) Schrader in Schrader and Fenner (low and high focus, width $52 \mu \mathrm{m}$ ).

7 Anaulus sp. (length $26 \mu \mathrm{m}$ ).

8 Hemiaulus polycistinorum Ehrenberg (width $86 \mu \mathrm{m}$ ).
9, 12 Thalassiosira sp.? cf. T. mediaconvexa Schrader in Schrader and Fenner. 9, diameter $22 \mu \mathrm{m} ; 12$, diameter $21 \mu \mathrm{m}$.

10 Asterolampra gradiata Gombos in Gombos and Ciesielski (diameter $62.7 \mu \mathrm{m}$ ).

11 Thalassiosira sp.? cf. T. manifesta SheshukovaPoretzkaya (diameter $28 \mu \mathrm{m}$ ).

13 Asterolampra punctifera (Grove) Hanna (diameter $45.5 \mu \mathrm{m})$. 

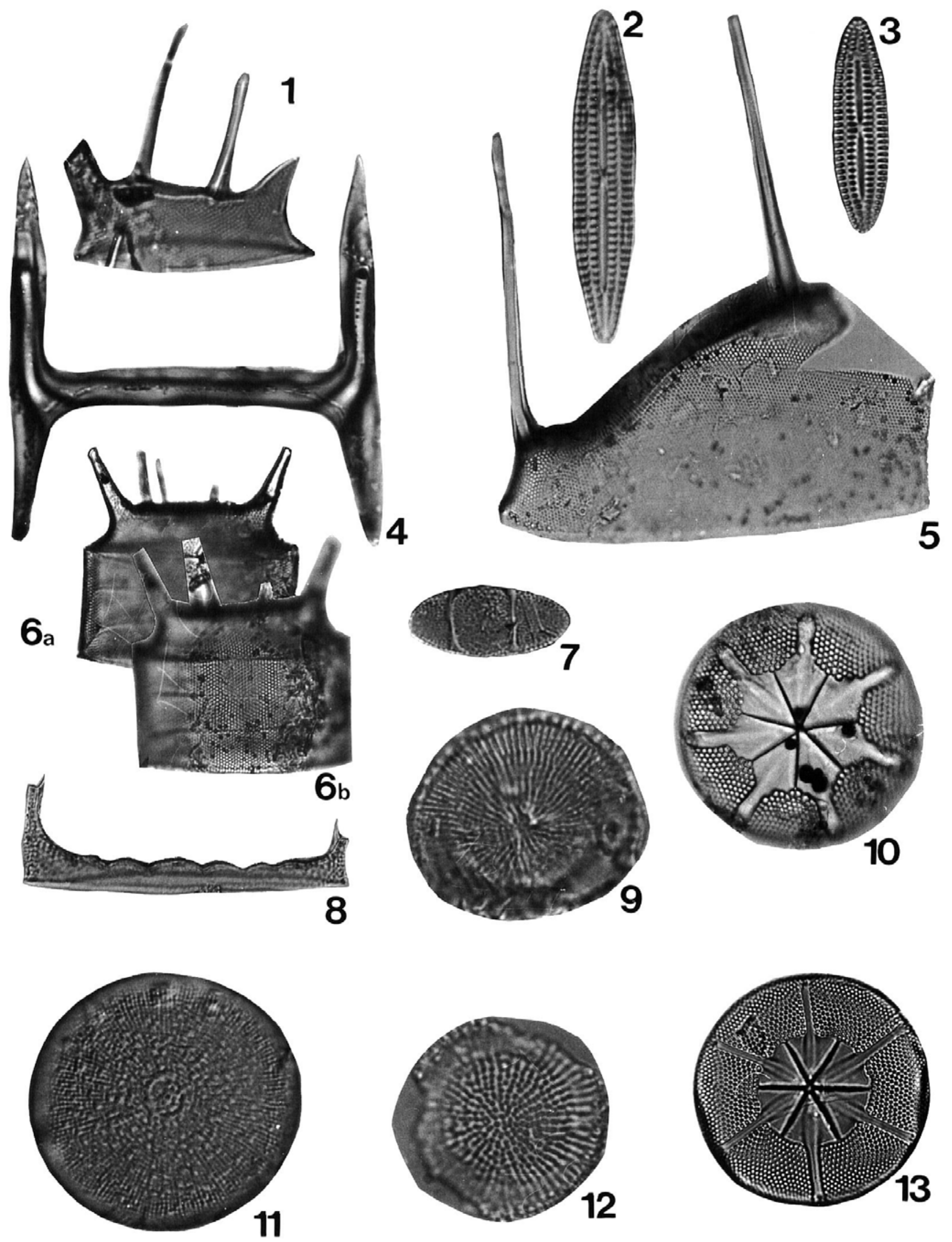
Hemiaulus danicus Grunow; Harwood 1989, p. 79, pl. 4, fig. 2, pl. 5, fig. 26.

Plate 7, figure 6

Hemiaulus dissimilis? Grove and Sturt; Harwood 1989, p. 79, pl. 4, figs. 3-5, 9, 10; pl. 5, fig. 25.

Plate 7, figure 12

Hemiaulus incisus Hajós 1976, p. 829, pl. 23, figs. 4-9; Gombos and Ciesielski 1983, p. 602, pl. 2, fig. 6; Harwood 1989, pl. 4, fig. 6.

Plate 7, figure 9

Hemiaulus polycistinorum Ehrenberg; Harwood 1989, pl. 4, fig. 13. Plate 4, figure 8; plate 7, figure 11

Hemiaulus polymorphus Grunow

Plate 7, figure 10

\section{Hemiaulus sp. A}

Plate 3, figure 7

Remarks: Only a single specimen was observed.

Kannoa hastata Komura 1980, p. 376, text-fig. 3, pl. 46, figs. 13a, b. As Ikebia tenuis (Brun) Akiba 1986, p. 439, pl. 19, figs. 1-5; Harwood 1989, p. 79, pl. 4, fig. 34; Goniothecium tenue var. structuralis Schrader and Fenner 1976, p. 983, pl. 37, figs. 6, 8, 9. Plate 5, figures 8,12 ; plate 7 , figure 5

Remarks: Akiba (1986, p. 440) followed Komura (1980) in suggesting that Ikebea may be a resting spore of Kannoa, because he observed colonies of Ikebea and Kannoa valves, with the former being inside, in an early Miocene assemblage from Japan.

Kannoa japonica Komura 1980, p. 374, text-figs. 2, pl. 46, figs. $1-12$.

Plate 5, figure 6; plate 7, figure 7

Kisseleviella carina Sheshukova-Poretzkaya; Harwood 1986, p. 86, pl. 6, figs. 12-15; Harwood 1989, p. 79, pl. 4, figs. 35-37.

Plate 5, figure 11
Liradiscus ovalis Greville; Harwood 1989, pl. 3, fig. 36. Plate 5, figure 15

Maluina sp.

Plate 6, figure 9

Remarks: See Ross and Sims 1987, p. 285 for the definition of this genus.

Muelleriopsis limbata (Ehrenberg) Hendey; Hajós 1976, p. 826, pl. 11, figs. $1-3$.

Navicula udintsevii Schrader and Fenner 1976, p. 991, pl. 22, fig. 33, pl. 24, figs. 1?, 2; Gombos and Ciesielski 1983, p. 602, pl. 21, fig. 8; Harwood and Maruyama, 1992, pl. 2, fig. 12.

Plate 6, figure 10

Odontella fimbriata (Greville) Schrader in Schrader and Fenner 1976, p. 992, pl. 20, fig. 6. As Biddulphia fimbriata Greville sensu Hajós 1976, p. 828, pl. 22, figs. 7, 8. As Odontella aurita (Lyngbye) Agardh group in Harwood 1989, p. 79, pl. 4, fig. 14.

Plate 4 , figures $6 a, b$

Odontella. sp. cf. O. fimbriata (Greville) Schrader in Schrader and Fenner.

Plate 4, figure 1

Remarks: Form with unequal processes.

\section{Odontella sp.}

Plate 4, figure 5

Remarks: Single specimen observed.

Pseudotriceratium adlerii Mahood, n. sp. in Mahood et al., in press; As Genus and species uncertain \#3 of Gombos and Ciesielski 1983, p. 606 , pl. 25 , figs. 8,9 .

Plate 3, figures 1, 2a,b

Remarks: Differs from Pseudotriceratium by deep mantle, swollen hypovalve and possible heterovalvate condition.

PLATE 5

1,2 Rhizosolenia oligocaenica Schrader. 1, length $66 \mu \mathrm{m} ; 2$, length $68 \mu \mathrm{m}$.

3 Rhizosolenia sp. C of Harwood 1989 (length $91 \mu \mathrm{m}$ ).

4 Pterotheca sp. D of Harwood 1989 (length $50 \mu \mathrm{m}$ ).

$5 \quad$ Rutilaria sp. (length $40 \mu \mathrm{m}$ ).

6 Kannoa japonica Komura (length $53 \mu \mathrm{m}$ ).

7 Sceptroneis pesplanus Fenner and Schrader in Schrader and Fenner (length $36.5 \mu \mathrm{m}$ ).

8, 12 Kannoa hastata Komura. 8, length $24 \mu \mathrm{m}$; 12, length $16 \mu \mathrm{m}$.
9 Sceptroneis talwanii Schrader and Fenner (length $165 \mu \mathrm{m})$.

10 Sceptroneis lingulatus Fenner (width $14 \mu \mathrm{m}$ ).

11 Kisseleviella carina Sheshukova-Poretzkaya (length $35 \mu \mathrm{m})$.

13, 16 Resting spore A. 13, width $10 \mu \mathrm{m} ; 16$, length $27 \mu \mathrm{m}$.

14 Chaetoceros panduraeformis (Pantocsek) Gombos in Fenner (with $38 \mu \mathrm{m}$ ).

15 Liradiscus ovalis Greville (width $19 \mu \mathrm{m}$ ).

17,19 Resting spore B. 17 , length $23 \mu \mathrm{m} ; 19$, length $28 \mu \mathrm{m}$.

18 Resting spore C (diameter $12.5 \mu \mathrm{m})$. 


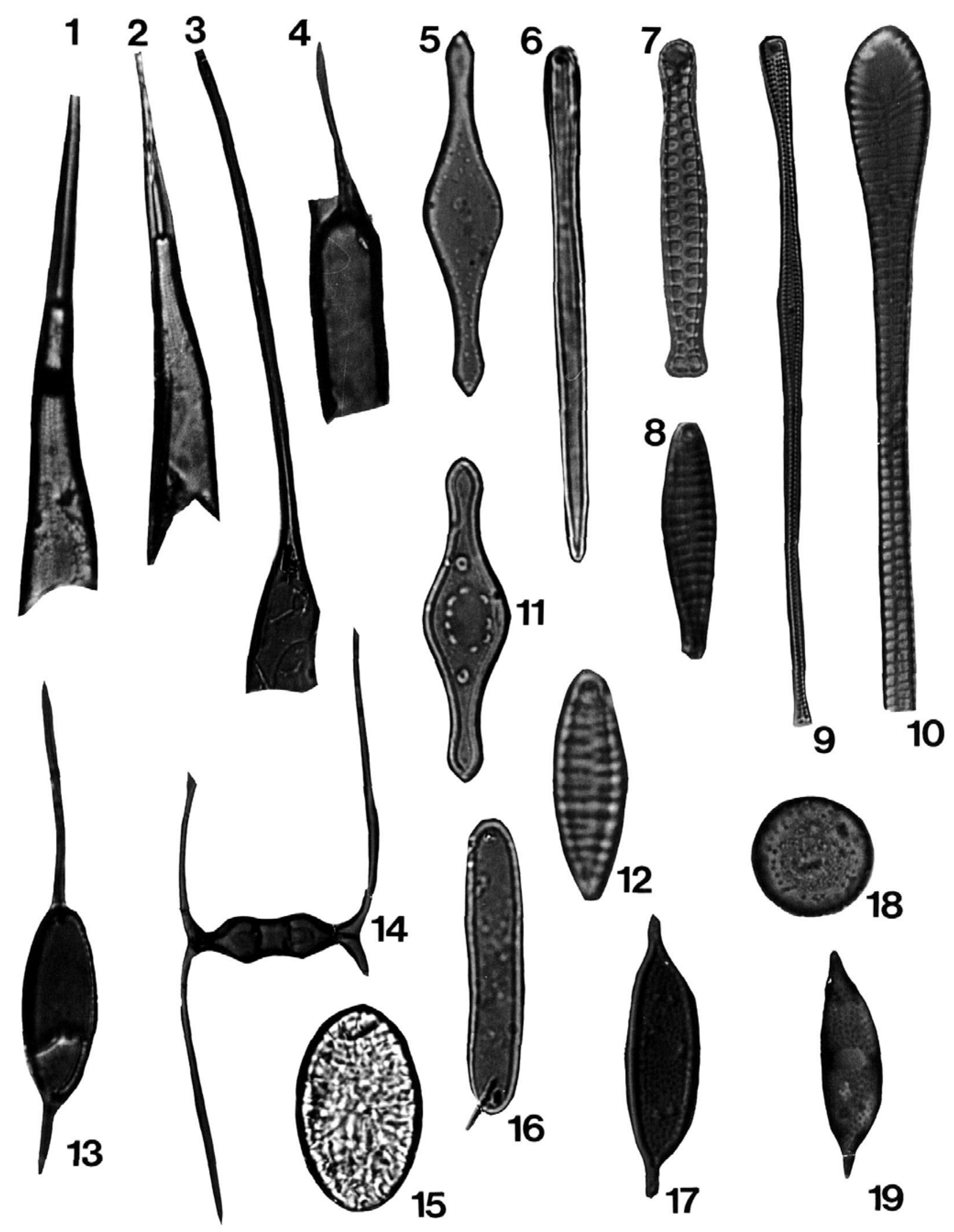


Pseudotriceratium radiosoreticulatum Grunow in Van Heurck; Gombos and Ciesielski 1983, p. 603, pl. 17, figs. 1-3; Harwood 1989, p. 80 , pl. 3 , figs. 14,15 .

Plate 3 , figure 5

\section{Pseudotriceratium sp.}

Plate 3, figures $4 a, b$

Pterotheca clavata Strelnikova, Harwood 1988, p. 86, fig. 13.32.

Pterotheca sp. D of Harwood 1989, p. 80, pl. 5, fig. 16, 17.

Plate 5, figure 4

Pyxilla reticulata Grove and Sturt; Fenner 1985, p. 735, figs. 11.611.10.

Plate 7, figures 1-3

Remarks: Frustules are covered with split ring girdle bands (see pl. 7, fig. 3) which resemble the girdle bands of Rhizosolenia alata Brightwell according to Strelnikova and Nikolayev (1989). This implies that Pyxilla is a resting spore of a Rhizosolenia-like diatom as suggested by Strelnikova and Nikolayev (1989).

Rhizosolenia oligocaenica Schrader 1976, p. 635, pl. 9, fig. 7. As $R$. gravida Gombos and Ciesielski 1983, p. 606, pl. 11, figs. 1-7; Harwood and Maruyama, 1992, pl. 4, fig. 17.

Plate 5, figures 1, 2

Rhizosolenia sp. C of Harwood 1989, pl. 3, fig. 25

Plate 5, figure 3

Rouxia granda Schrader in Schrader and Fenner 1976, p. 997, pl. 7, fig. 17.

Plate 4, figures 2, 3

\section{Rutilaria sp.}

Plate 5, figure 5

Sceptroneis lingulatus Fenner 1978, p. 531, pl. 31, figs. 8-10; Gombos and Ciesielski 1983, p. 604, pl. 24, fig. 8; Harwood 1989, p. 80 , pl. 6, fig. 11. (Ornamented valve - pl. 5, fig. 10.)

Sceptroneis pesplanus Fenner and Schrader in Schrader and Fenner 1976, p. 998, pl. 22, figs. 30, 31 and pl. 25, figs. 10, 11; Gombos and Ciesielski 1983, p. 604, pl. 21, fig 10?.

Plate 5, figure 7

Remarks: Valves without ornamentation most common.
Sceptroneis talwanii Schrader and Fenner 1976, p. 999, pl. 24, figs., $28,29$.

Plate 5, figure 9; plate 7, figures 4a, b

Skeletonema barbadensis Greville; Gombos and Ciesielski 1983, p. 605, pl. 5, figs. 1-4, pl. 21, fig. 4; Fenner 1985, p. 738, figs. 9.1, 9.2. Plate 6 , figure 1

Remarks: SEM studies underway reveal 4-5 evenly spaced rimoportulae around the margin. Marginal connecting processes appear to be hollow but no openings could be resolved on the internal valve surface.

Sphynctolethus pacificus (Hajós) Sims 1986, pp. 250-252, figs. 29-34; Harwood 1989, p. 80, pl. 5, figs. 18-27.

Plate 6, figure 5

Stellarima stellaris (Roper) Hasle and Sims; Harwood 1989, pl. 1, fig. 3 .

Plate 1 , figures 4,5

Stephanopyxis grunowii Grove et Sturt in Schmidt; Hajós 1976, p. 824, pl. 3, figs. 3, 4, pl. 4, figs. 1, 2; Harwood 1989, p. 81, pl. 2, figs. 5,6 .

Plate 2, figures 1a-c

Stephanopyxis oamaruensis Hajós 1976, p. 825, pl. 19, fig. 280; Harwood 1989, p. 81, pl. 2, figs. 27-29.

Plate 2, figure 5

Stephanopyxis splendidus (Greville) Harwood 1989, p. 81, pl. 2, figs. 1-4.

Plate 2, figure 2.)

Remarks: Thalassiosira hydra Gombos in Gombos and Ciesielski 1983, p. 606, pl. 7, figs. 1-6 is identified by Harwood (1989) as the resting spore of $S$. splendidus.

Stephanopyxis superba (Greville) Grunow; Hajós 1976, p. 825, pl. 1, figs. 11-13; Harwood 1989, p. 81, pl. 2, figs. 14-20, 26.

Plate 2, figures 3,4

Stephanopyxis turris (Greville and Arnott) Ralfs; Harwood 1989, p. 81 , pl. 2, figs. 21-23.

Plate 6, figure 8

Remark: Semi-endogenous resting spore.

PLATE 6

1 Skeletonema barbadensis Greville (scale bar $=4 \mu \mathrm{m})$.

2a, b Thalassiosira? sp. cf. T. manifesta Sheshukova-Poretzkaya $(2 \mathrm{a}$, scale bar $=4 \mu \mathrm{m} ; 2 \mathrm{~b}$, details of margin, scale bar $=1 \mu \mathrm{m}$.

3, 4 Chaetoceros sp. (scale bar $=20 \mu \mathrm{m}$ ). 3, resting spores, arrows.

$5 \quad$ Sphynctolethus pacificus $($ scale bar $=20 \mu \mathrm{m})$.
6,7 C. panduraeformis $($ scale bar $=20 \mu \mathrm{m})$.

8 Stephanopyxis turris (scale bar $=20 \mu \mathrm{m}$, resting spore, arrow).

$9 \quad$ Maluina sp. (scale bar $=10 \mu \mathrm{m})$.

10 Navicula udintsevii $($ scale bar $=20 \mu \mathrm{m})$. 

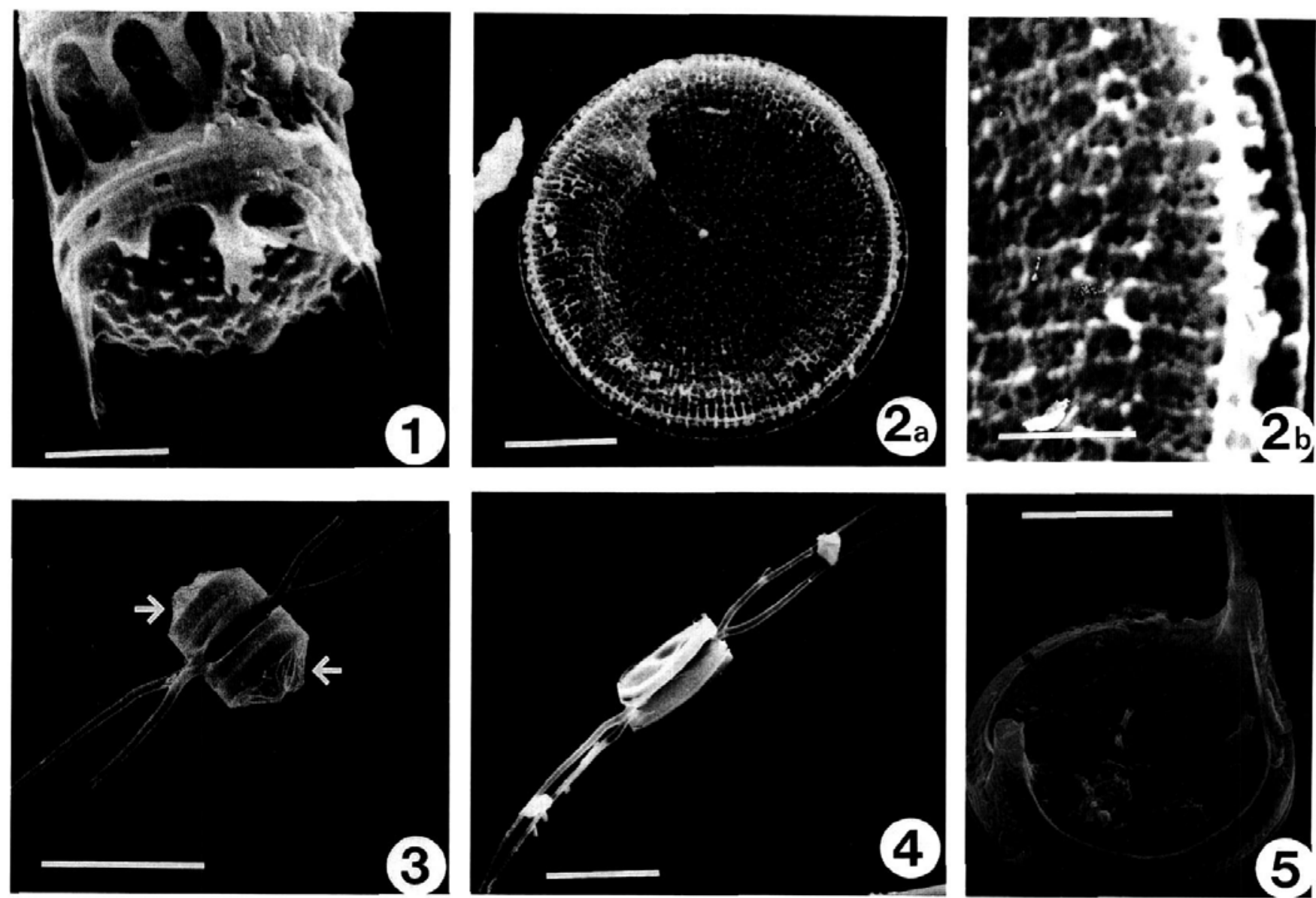

4
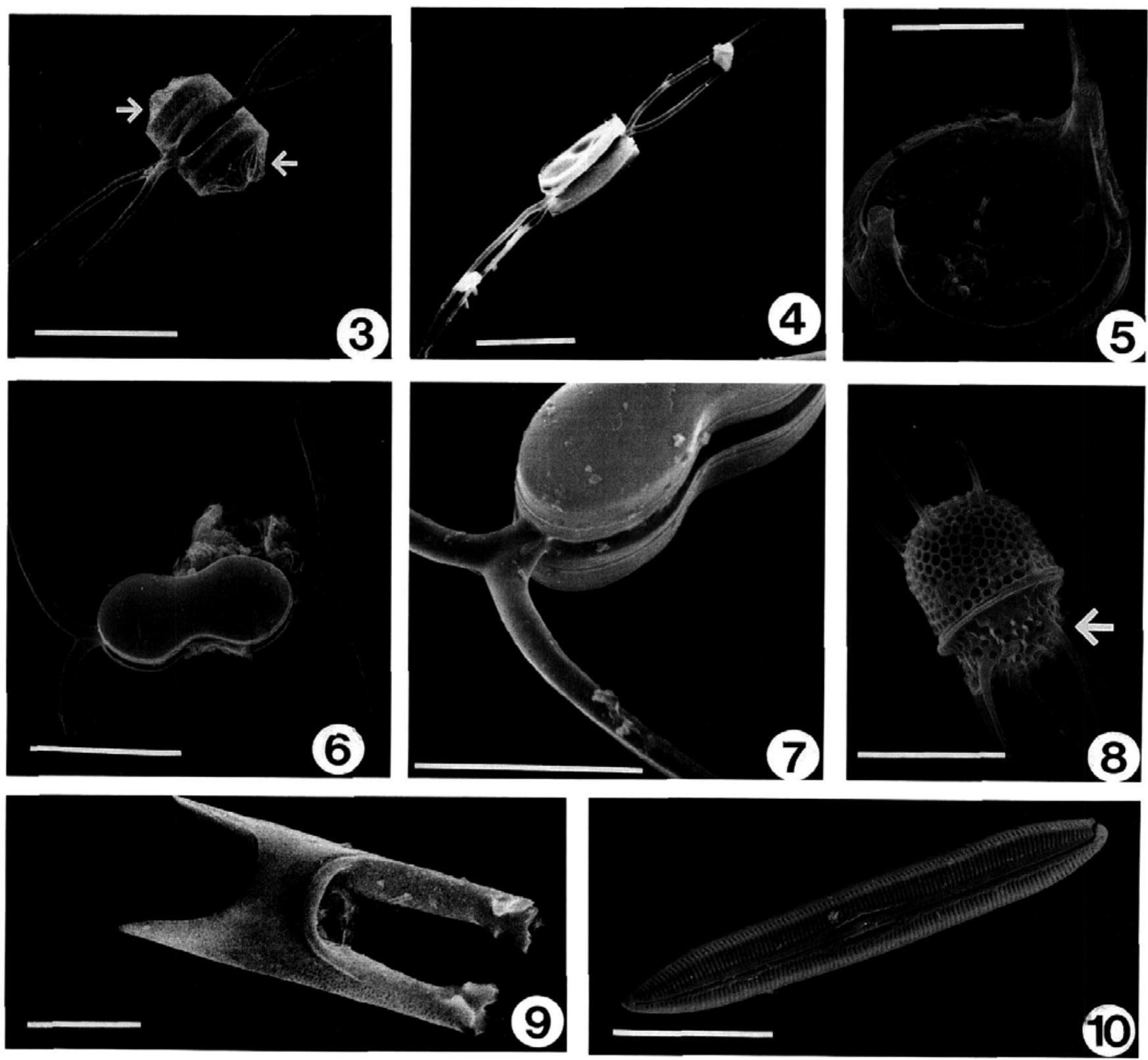
Stictodiscus kittonianus Greville; Schrader and Fenner 1976, p. 1001 , pl. 35, fig. 27; Harwood 1989, p. 81, pl. 1, figs. 7, 8 .

Plate 2, figure 8

Thalassiosira? cf. T. manifesta Sheshukova-Poretzkaya. Compare Porosira glacialis (Grunow) Joergensen sensu Schrader and Fenner 1976, pl. 16, figs. 3, 13 .

Plate 4, figure 11 ; plate 6 , figures $2 \mathrm{a}, \mathrm{b}$

Thalassiosira? mediaconvexa Schrader in Schrader and Fenner 1976, p. 1002, pl. 36, fig. 1.

Plate 4, figures 9,12

Triceratium polymorphus Harwood and Maruyama, 1992, p. 605, pl. 1, figs. 1-3. As T. macroporum Hajós sensu Gombos and Ciesielski 1983, pl. 17, fig. 6. As T. hebetatum (Grunow) Andrews forms A, B and C in Harwood 1989, pp. 81-82, pl. 3, figs. 2-6.

Plate 3, figures 6, 9

Trinacria excavata Heiberg; Hajós 1976, pl. 14, fig. 9, pl. 15, figs. 8, 9; Harwood 1989, p. 82, pl. 3, fig. 1.

Plate 3, figure 3

Tumulopsis fogedi Hendey 1982, p. 277, pl. 1, figs. 1-3.

Plate 2, figures 7, 10 (ornamented valves); plate 2, figure 9 (plain valves)

Synonyms: Cotyledon fogedi (Hendey) Harwood 1989, p. 78, pl. 4, figs. 30, 31 (sparsely ornamented spore valve); Genus and species uncertain \#2 of Gombos and Ciesielski 1983, p. 606, pl. 25, figs. 5-7; Podosira polita Hanna and Grant sensu Gombos and Ciesielski 1983, p. 603, pl. 4, fig. 11 (differs from type slide CAS 201009 of $P$. polita).
Remarks: According to De Toni in Van Heurck (1896, p. 519), the generic name Cotyledon is a later homonym of a plant genus and should be rejected. The junior synonym Gutwinskiella De Toni (1894) is not available to replace Cotyledon, because Gutwinskiella clypeolus (Brun) De Toni, the type species for the genus Gutwinskiella, is apparently a species of Acanthodiscus (Van Heurck 1896). Another possibility to replace the name Cotyledon would be Bruniella, which Van Heurck (1896, p. 512) proposed for specimens that were named Cotyledon cornalis by Brun (1891, p. 24, pl. 11, fig. 3). Brun's (1891, pl. 11 , fig. 3 ) drawing of $C$. cornalis resembles $T$. fogedi, suggesting that the latter taxon should be transferred to Bruniella; however, study of Brun's (1891) type material is required for confirmation.

This diatom also resembles Hyalodiscus elegans Strelnikova sensu Baldauf and Barron 1987, p. 6, pl. 1 fig. 2.

Similar to Harwood (1989), we observed ornamented valves attached to plain valves.

Xanthiopyxis sp. ?; As genus and species indet. 1 of Fenner 1978, pl. 34, figs. 16-18.

\section{Resting spore $\mathbf{A}$}

Plate 5, figures 13,16

\section{Resting spore $B$}

Plate 5, figures 17,19

Remark: Similar forms have been observed as modern resting spores of Chaetoceros by A. D. Mahood in San Francisco Bay.

\section{Resting spore $\mathbf{C}$}

Plate 5, figure 18

\section{PLATE 7}

$1,2,3$ Pyxilla reticulata. 1 , scale bar $=40 \mu \mathrm{m} ; 2$, scale bar $=$ $10 \mu \mathrm{m}$, split ring girdle band, arrow; 3 , scale bar $=20 \mu \mathrm{m}$, split ring girdle band, arrow.

4a,b Sceptroneis talwanii. 4a, internal head pole view, arrow points to labiate process, scale bar $=4 \mu \mathrm{m} ; 4 \mathrm{~b}$, internal foot pole view, arrow points to labiate process, scale bar $=4 \mu \mathrm{m})$.

$5 \quad$ Kannoa hastata $($ scale bar $=10 \mu \mathrm{m})$.

6 Hemiaulus danicus $(\mathrm{scale}$ bar $=10 \mu \mathrm{m})$
$7 \quad$ K. japonica $($ scale bar $=10 \mu \mathrm{m})$.

8 Baxteriopsis brunii $($ scale bar $=20 \mu \mathrm{m})$.

$9 \quad$ H. incisus $($ scale bar $=10 \mu \mathrm{m})$.

10 H. polymorphus (scale bar $=20 \mu \mathrm{m}$ ).

11 H. polycistinorum $($ scale bar $=10 \mu \mathrm{m})$.

$12 H$. dissimilis (scale bar $=10 \mu \mathrm{m})$. 

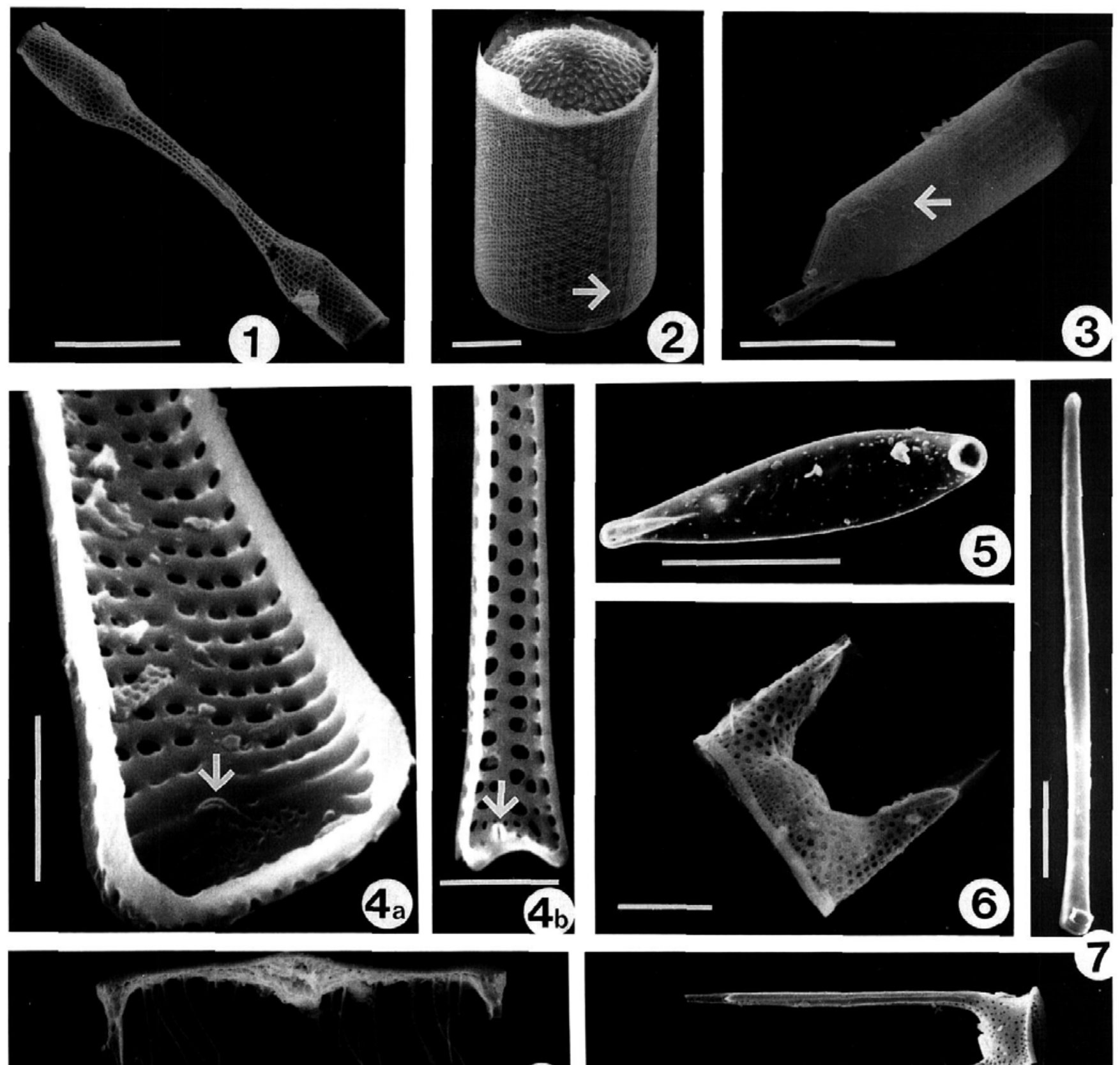

8
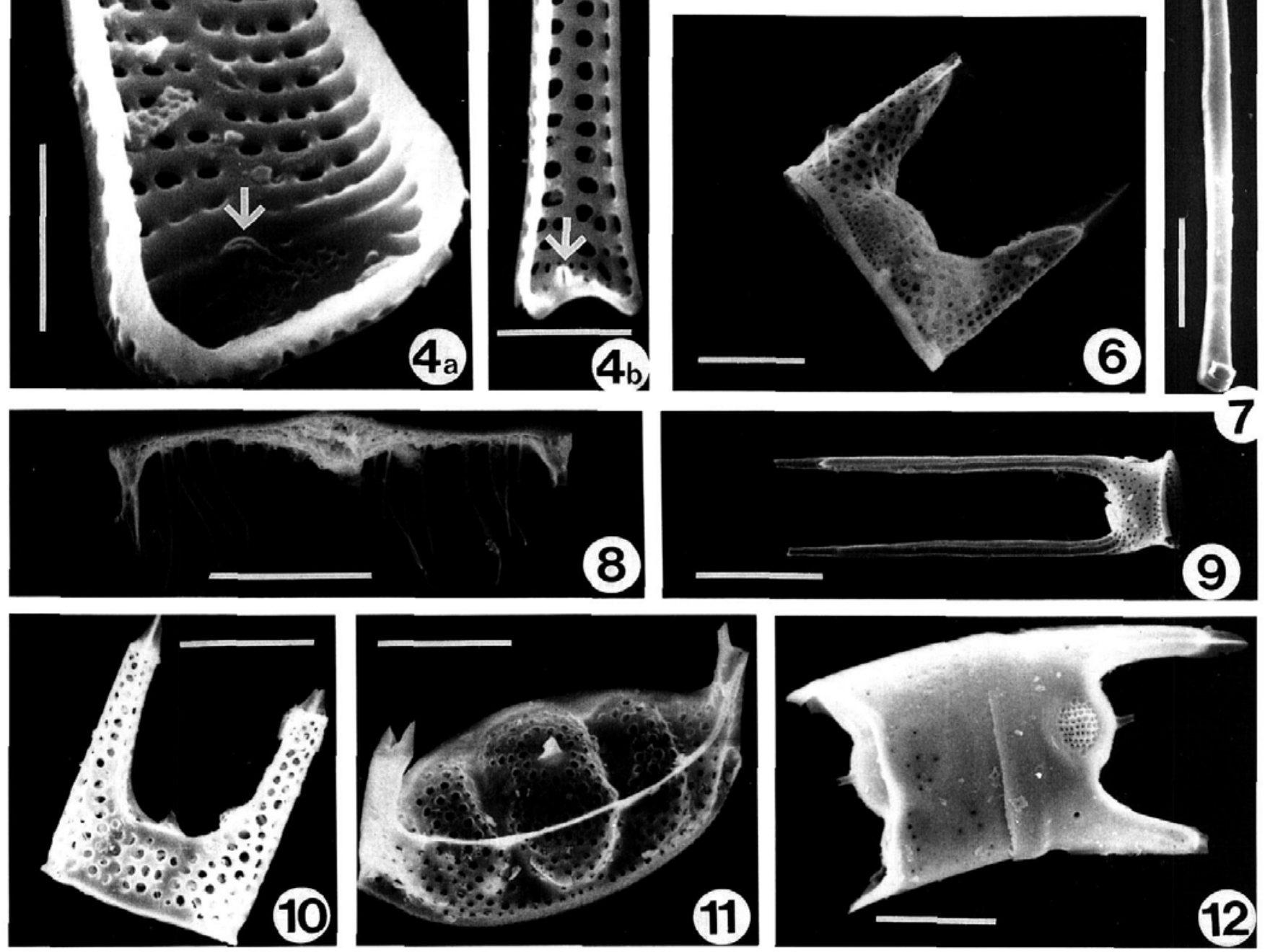